\title{
Studies of Enteric Pathogens and $\gamma$-Globulin Levels of Neonatal Calves in Sweden
}

\author{
By S. Viring, S.-O. Olsson, S. Alenius, U. Emanuelsson, S.-O. Jacobsson, B. Larsson, N. Linde \\ and $A$. Uggla
}

Animal Health Service, Swedish Meat Marketing Association and Division of Cattle, Sheep and Pigs, National Veterinary Institute, Uppsala, Swedish Association for Livestock Breeding and Production, Eskilstuna, Department of Cattle and Sheep Diseases, Veterinary Faculty, Swedish University of Agricultural Sciences, Uppsala, Laboratory of Virology, National Veterinary Institute, Biomedicum, Uppsala, and Laboratory of Parasitology, National Veterinary Institute and Swedish University of Agricultural Sciences, Uppsala, Sweden.

\begin{abstract}
Viring, S., S.-O. Olsson, S. Alenius, U. Emanuelsson, S.-O. Jacobsson, B. Larsson, N. Linde and A. Uggla: Studies of enteric pathogens and $\gamma$-globulin levels of neonatal calves in Sweden. Acta vet. scand. 1993, 34, 271-279. - Faecal and blood samples were taken from $10-30 \%$ of calves, 36 hours to 14 days old, in 47 dairy herds in different regions of Sweden from September 1987 to October 1988 (Olsson et al. 1993).

Faecal samples from 279 calves were analysed for the presence of Escherichia coli $\left(\mathrm{K} 99^{+}\right)$, rotavirus and Cryptosporidium sp. Twenty $(7.2 \%)$ of these samples were from diarrhoeic calves. An ELISA was developed and used for the rotavirus analysis. E. coli $\mathrm{K} 99^{+}$was detected in $11.5 \%$, Cryptosporidium sp. in $6.1 \%$ and rotavirus in $5.4 \%$ of the faecal samples. The presence of rotavirus alone and the combination rotavirus and $\mathrm{E}$. coli $\left(\mathrm{K} 9^{+}\right)$was found to be associated with diarrhoea $(\mathrm{p}<0.001$ and $\mathrm{p}<0.01$ respectively).

Blood samples from 327 calves were analysed for the level of total protein and $\gamma$-globulin. In 43 of these samples (13\%) $\gamma$-globulin did not separate from the $\beta_{2}$-region by electrophoresis. The mean total protein concentration was $53.6 \mathrm{~g} / \mathrm{l}$ in calves free from diarrhoea. The mean $\gamma$-globulin concentration, adjusted to 7 days age was $5.9 \mathrm{~g} / \mathrm{l}$. The 20 diarrhoeic calves had lower levels of both total protein and $\gamma$-globulin, compared with calves without diarrhoea, but the difference was not significant.

One litre more of colostrum at the first feed increased the level of total protein of the calves' sera by $1.4 \mathrm{~g} / \mathrm{l}(\mathrm{p}=0.05)$. Calves born between May and September had a $2.0 \mathrm{~g} / \mathrm{l}$ higher $(p<0.001)$ serum concentration of $\gamma$-globulin than calves born between October and April.
\end{abstract}

calf diarrhoea; Cryptosporidium sp.; E. coli $\left(\mathrm{K}^{9} 9^{+}\right)$; rotavirus; $\gamma$-globulin; total protein; colostrum.

\section{Introduction}

Enteritis is one of the most common diseases affecting neonatal calves throughout the world. Enteritis was $7.2 \%$ in a Swedish study (Olsson et al. 1993) of calves 0-90 days old. In Denmark, enteritis was observed in $44 \%$ of calves sent for destruction (Krogh 1971), while in Germany, $88 \%$ of necropsied calves were found to have a complex of abomasitis, enteritis and pneumonia (Plöger et al. 1980). The aetiology of bovine neonatal diarrhoea is complex and includes weak maternal immunity, nutritional factors, unsuitable management and a variety of infectious agents such as rotavirus, coronavirus, bovine virus diar- 
rhoea virus, Escherichia coli $\mathrm{K}^{9} 9^{+}$, Salmonella sp. and Cryptosporidium parvum (Bridger et al. 1978; Tzipori 1981, Linthermans \& Pohl 1983, Baker et al. 1987, De Rycke et al. 1988, Roy 1990). All these microorganisms have been detected in Swedish calves. Rotavirus and Cryptosporidium sp. have only been detected in faeces of neonatal calves in a few farms (Moreno-López \& Jacobsson 1978, Viring et al. 1985) and the association between these microorganisms have never been ruled out.

An adequate supply of colostrum and thereby the transfer of maternal antibodies to the newborn calf is most important for the prevention of enteritis and septicaemia (e.g. Blom 1982, Larsson 1985). Maternal antibodies are absorbed by the intestine and are found in the $\gamma$-globulin fraction of blood serum. The quantity of transferred immunoglobulins (Ig) depends on several factors, such as duration between partus and ingestion of colostrum, the content of $\mathrm{Ig}$ in colostrum, amount of ingested colostrum, breed, parity and individual factors (Kruse 1970 a,b). The concentration of $\mathrm{Ig}$ in serum peaks within a few days of birth. The half-life of the predominant $\mathrm{Ig}$ in serum, $\mathrm{IgG1}$, is reported to be 17 21 days (Logan et al. 1972, Tizard 1987). The serum level of Ig in Swedish 2 to 5 week old calves was studied by Hurvell \& Fey (1971) and Larsson (1985), but data is missing for younger calves. Nor have studies been carried out to determine the relation between various enteric pathogens, diarrhoea and serum level of Ig in Swedish dairy calves.

The objectives of this study were (a) to investigate the prevalence of 3 infectious agents (rotavirus, Cryptosporidium sp. and E. coli $\left(\mathrm{K} 99^{+}\right)$) in faeces of diarrhoeic and non-diarrhoeic calves in Swedish dairy herds, and (b) to correlate the presence of diarrhoea to levels of total protein and $\gamma$-globulin concentra- tion in serum, and (c) to correlate the levels of total protein and $\gamma$-globulin in serum to geographical region of the herd, season of birth, parity of the dam, breed, age at the first colostrum feeding and amount of the first colostrum fed.

\section{Materials and methods}

Calves and samples

Forty-seven herds were selected by convenience from a 200 -herd survey of diseases in neonatal calves in Sweden, described by Olsson et al. (1993). The herds were from 10 regions representing different areas of Sweden. Blood and faecal samples were obtained by practising veterinarians from 327 and 279 calves respectively in the age range $36 \mathrm{~h}$ up to 14 days. The samples comprised as a rule 20 $30 \%$ and at least $10 \%$ of the calves born within the herd from September 1987 to October 1988 . The calves were classified as diarrhoeic or non-diarrhoeic by the veterinarian, who also received the following information from the farmer: age of the calf at sampling, age at first colostrum given and amount of first colostrum feed.

\section{Examination of faecal samples}

For detection of Cryptosporidium oocysts, smears were made from non-concentrated faecal samples on glass slides, air dried, fixed in methanol for $3 \mathrm{~min}$ and subsequently exposed to formaldehyde vapour at room temperature for $30 \mathrm{~min}$. The smears were then stained by the phenol-auramine technique as described by Nichols \& Thom (1984) and examined under an incident-light fluorescence microscope (Olympus, Tokyo, Japan) at 200x and $400 \mathrm{x}$ magnification.

E. coli strains were isolated from faecal samples with conventional methods (Cowan \& Steel 1974) at the National Veterinary Insti- 
tute. Two colonies from each sample were tested for K99 antigen by slide agglutination (Smyth et al. 1981).

For detection of rotavirus antigen in faeces, an enzyme-linked immunosorbent assay (ELISA) was developed. For this purpose, the serum Ig fraction from rabbits immunized 3 times with the rotavirus strain Osu and Gotfried was purified with protein A Sepharose and used as coating antigen at a concentration of $10 \mu \mathrm{g} / \mathrm{ml}$ carbonate buffer ( $\mathrm{pH}$ 9.6). After incubation overnight, the plates were washed twice with phosphate-buffered saline with $0.5 \%$ Tween 20 (PBS- $t$ ) and $200-\mu l$ volumes of faecal solution $(20 \%)$ in PBS-t were added per well in duplicate. After an incubation for $2 \mathrm{~h}$ at $37^{\circ} \mathrm{C}$ the plates were washed 3 times with PBS-t. Then $200 \mu \mathrm{l}$ of an optimal dilution of the conjugate in PBS-t with $5 \%$ bovine serum albumin was added per well. The conjugate was the Ig-preparation of the rabbit hyperimmune serum to rotavirus coupled to horse-radish peroxidase according to the method of Nakane \& Kawoi (1974). The plates were incubated for $30 \mathrm{~min}$ at $37^{\circ} \mathrm{C}$ and washed 3 times with PBS-t. Then $200 \mu \mathrm{l}$ of a substrate solution $(0.1 \mathrm{mg}$ tetramethylbenzidine $/ \mathrm{ml}$ and $0.05 \% \mathrm{H}_{2} \mathrm{O}_{2}$ in $0.05 \mathrm{M}$ citrate buffer, $\mathrm{pH}$ 5.5) was added to each well and the reaction was stopped after $15 \mathrm{~min}$ at room temperature by adding $50 \mu \mathrm{l} 2 \mathrm{M} \mathrm{H}_{2} \mathrm{SO}_{4}$. The absorbance was measured in a Multiscan spectrophotometer (Flow Laboratories, Irvine, Scotland) at $450 \mathrm{~nm}$. Faecal samples were considered positive for rotavirus antigen when the mean optical density was 2.5 -fold higher than that of a negative standard.

\section{Analysis of blood samples}

Total protein concentration was measured with the biuret reaction performed in a computerized multichannel spectrophotometer (Cobas Mira, Hoffman-La Roche, Switzer- land). The coefficient of variation between assays ranged between $1.3 \%$ and $2.2 \%$.

Serum protein electrophoresis was performed using cellulose acetate strips as carrier medium and a $0.05 \%$ barbiturate buffer solution ( $\mathrm{pH}$ 8.6). The electrophoresis was run for 20$30 \mathrm{~min}$ at $20 \mathrm{~V} / \mathrm{cm}$ and a current of $<10 \mathrm{~mA}$.

The concentration of $\gamma$-globulin was adjusted for age to an estimated value corresponding to a calf age of 7 days ( $\gamma$-globulin 7$)$ according to the formula:

$[\gamma$-globulin $] 7=[\gamma \text {-globulin }]_{a} \times e^{\mathrm{dk}}$ where

[ $\gamma$-globulin $]_{a}$ is the concentration of $\gamma$-globulin at the age of sampling in days $(a), d$ is $a-7$ and $k$ is the quota of $\ln 2$ and the considered halflife of $\mathrm{IgG}_{1}, 17$ days (Tizard 1987).

\section{Statistical methods}

The correlation between microorganisms isolated in faecal samples and diagnosis of diarrhoea was calculated using Fisher's Exact test for $2 \times 2$ tables. Differences between calves with and without diarrhoea with regard to total serum protein, serum $\gamma$-globulin, and time and amount of first colostrum feeding were assessed with an ordinary Student's $t$-test. Least-squares analysis of variance was performed in order to investigate the effects of some factors on the concentrations of total protein and $\gamma$-globulin in serum. Independent variables were geographical region of the herd, season of birth, breed and parity of the cow, age in hours at first colostrum feeding and amount of first colostrum fed. Non-significant ( $p>0.05$ ) factors were removed from the model by a backward stepwise procedure. Data from the official milkrecording scheme (Swedish Association for Livestock, Breeding and Production, Eskilstuna, Sweden) and from the information furnished by the farmer were used for this analysis. 


\section{Results}

Microorganisms in faecal samples

Of the 279 faecal samples bacteriologically examined, $32(11.5 \%)$ proved positive for the presence of E. coli $\left(\mathrm{K}^{9} 9^{+}\right)$. Cryptosporidium was found in $17(6.1 \%)$ and rotavirus antigen in $15(5.4 \%)$ of the samples. Of the faecal samples examined, $20(7.2 \%)$ were from diarrhoeic calves, as determined by the field veterinarian. At least 1 of the 3 pathogens was detected in $11(55 \%)$ of these 20 samples (Table 1$)$, which is a significantly higher detection rate $(\mathrm{p}<0.001)$ than in non-diarrhoeic samples $(18 \%)$. Detection of rotavirus antigen, alone or together with $E$. coli, was associated with diarrhoea ( $\mathrm{p}<0.001$ and $\mathrm{p}<0.01$, respectively). In contrast, the presence of Cryptosporidium or E. coli $\left(\mathrm{K} 99^{+}\right)$alone was not generally associated with diarrhoea (Table 1).

\section{Total protein and $\gamma$ globulin in serum}

Blood samples from 327 calves were analysed regarding content of total protein and $\gamma$-globulin. The $\gamma$-globulin fraction could not be separated from the $\beta_{2}$ fraction in $43(13 \%)$ of the samples. These samples were omitted in the statistics.

The mean total protein and $\gamma$-globulin values in relation to age of the calves are shown in Figs. 1 and 2. The concentration of total protein was in the same range in calves from 2 to 14 days old, whereas the $\gamma$-globulin concentration decreased with increasing age $(\mathrm{p}<0.05)$. As shown in Table 2, the mean concentration of total protein in non-diarrhoeic calves was $53.6 \mathrm{~g} / \mathrm{l}$ (range 39-76 g/l) and that concentration of $\gamma$-globulin recalculated to 7 days of age was $5.9 \mathrm{~g} / \mathrm{l}$ (range $1-16 \mathrm{~g} / \mathrm{l})$.

\section{Various factors in relation to diarrhoea}

As can be seen from Table 2 the concentrations of total serum protein and $\gamma$-globulin were somewhat lower in calves with diarrhoea than in non-diarrhoeic calves, but the differences were not significant. Nor was there any significant difference between diarrhoeic and non-diarrhoeic calves in quantity of first colostrum fed or regarding the time when the first colostrum feed after birth was given (Table 2).

Table 1 . The presence of microorganisms in faeces in relation to diarrhoea in 279 dairy calves aged $1 \frac{1}{2}-14$ days.

\begin{tabular}{|c|c|c|c|c|c|}
\hline \multicolumn{3}{|c|}{ Microorganism } & \multicolumn{2}{|c|}{ Diarrhoea } & \multirow[b]{2}{*}{ Probability* } \\
\hline $\begin{array}{l}\text { E. coli } \\
\left(\mathrm{K} 99^{+}\right)\end{array}$ & $\begin{array}{l}\text { Crypto- } \\
\text { sporidium }\end{array}$ & $\begin{array}{l}\text { rota- } \\
\text { virus }\end{array}$ & Yes & No & \\
\hline - & - & - & 9 & 212 & \\
\hline+ & - & - & 1 & 25 & 1.00 \\
\hline - & + & - & 1 & 13 & 0.47 \\
\hline - & - & + & 7 & 5 & $<0.001$ \\
\hline+ & + & - & 0 & 3 & 1.00 \\
\hline+ & - & + & 2 & 1 & 0.006 \\
\hline - & + & + & 0 & 0 & \\
\hline+ & + & + & 0 & 0 & \\
\hline
\end{tabular}

\footnotetext{
*Degree of association between pathogen status and diarrhoea as estimated with Fisher's exact test.

+ , microorganism detected.

- , microorganism not detected.
} 


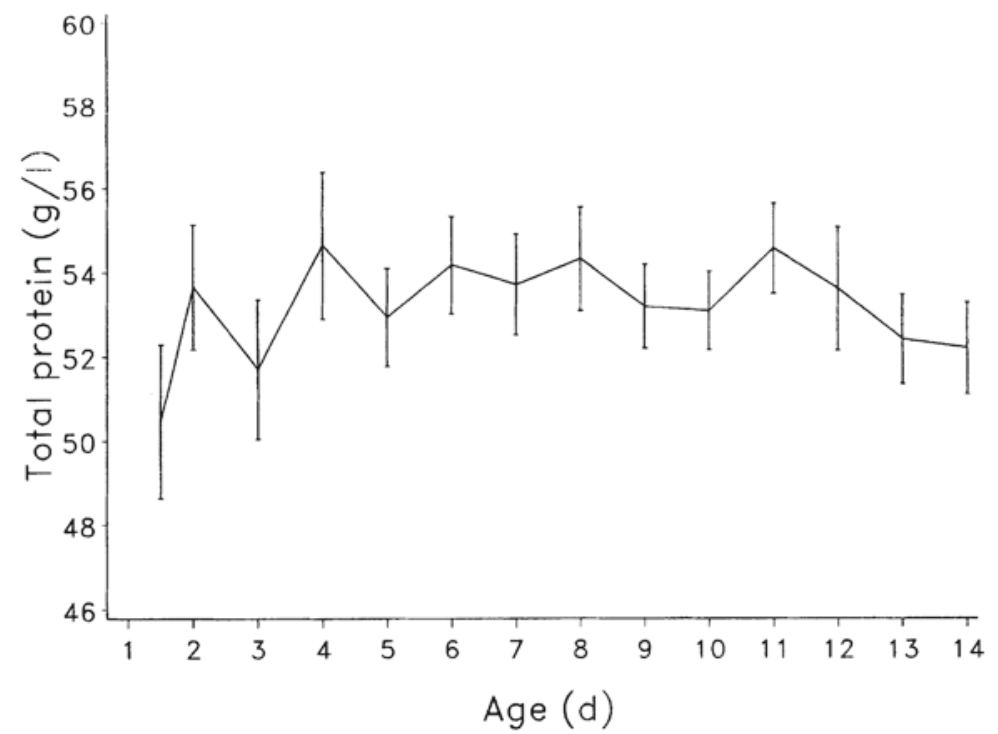

Figure 1. Mean ( \pm SE) total protein level in serum of 327 calves $36 \mathrm{~h}$ to 14 days (d) old.

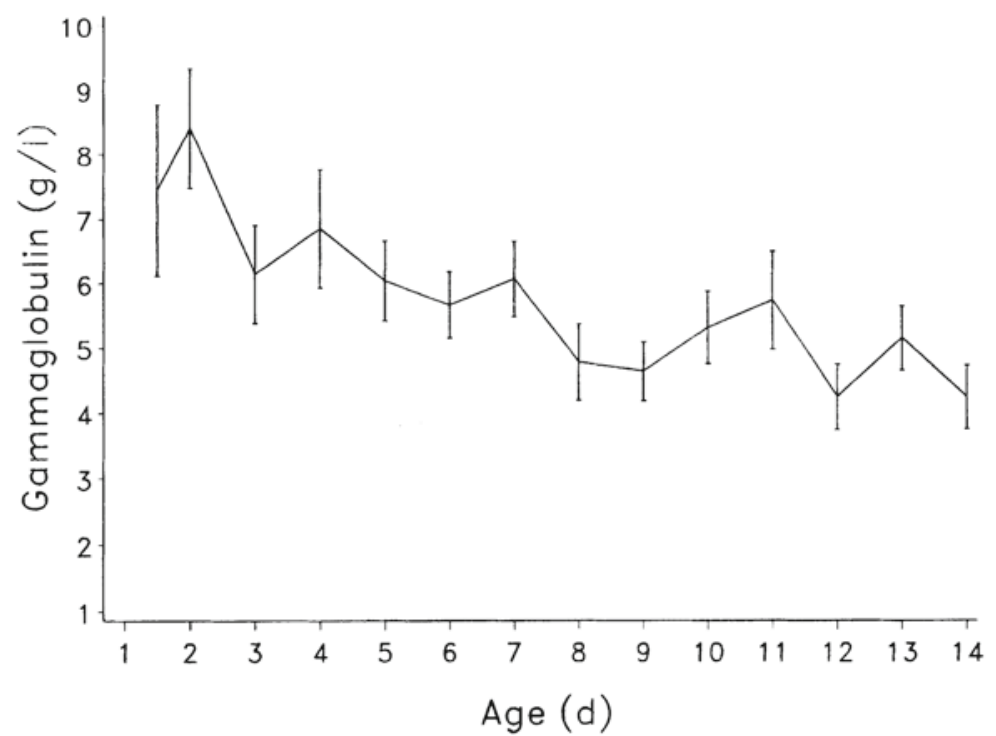

Figure 2. Mean ( \pm SE) gammaglobulin level in serum of 284 calves 36 hours to 14 days (d) old. 
Table 2. Overall means $( \pm \mathrm{SE})$ for recalculated gammaglobulin levels, total protein content and age at first colostrum feeding for calves with and without diarrhoea at the time of sampling ( $n=$ number of observations).

\begin{tabular}{lcccc}
\hline \multirow{2}{*}{ Variable } & $n$ & \multicolumn{2}{c}{ Diarrhoea } & Probability* \\
\cline { 3 - 4 } $\begin{array}{l}\text { Adjusted gamma- } \\
\text { globulin (g/l) }\end{array}$ & 284 & $\begin{array}{c}5.3 \pm 0.6 \\
(\mathrm{n}=25)\end{array}$ & $\begin{array}{c}5.9 \pm 0.2 \\
(\mathrm{n}=259)\end{array}$ & 0.373 \\
Total protein (g/1) & 327 & $\begin{array}{c}51.4 \pm 1.2 \\
(\mathrm{n}=26)\end{array}$ & $\begin{array}{c}53.6 \pm 0.4 \\
(\mathrm{n}=301)\end{array}$ & 0.117 \\
$\begin{array}{l}\text { Age at first (hours) } \\
\text { colostrum feed }\end{array}$ & 326 & $4.5 \pm 0.4$ & $3.9 \pm 0.1$ & 0.207 \\
\hline
\end{tabular}

*Student's $t$-test was used.

Various factors related to concentrations of protein and $\gamma$-globulin in serum

Errors in identifications of calves, and thus missing information on variables obtained from the milk recording scheme, reduced the number of observations in the final leastsquares analysis for $\gamma$-globulin and total protein to 196 and 177 respectively. The concentration of total protein in the serum of calves was significantly ( $p \leq 0.05)$ influenced by the amount of the first colostrum fed. Thus, each additional litre of colostrum increased the level of serum protein by $1.4 \mathrm{~g} / 1$ ( \pm SE 0.7$)$. The concentration of $\gamma$-globulin was $2.0 \mathrm{~g} / \mathrm{l}$ ( $\mathrm{SE} \pm 0.6$ ) higher in the calving season May to September than in October to April $(\mathrm{p}<0.001)$. Regarding region, breed, parity and age at first colostrum feed, no significant effect was evident with respect to the concentrations of $\gamma$-globulin and total protein in the serum of calves.

\section{Discussion}

The prevalence of diarrhoea in this study was $7.2 \%$ in $2-15$-day-old calves (Table 2). Diarrhoea was diagnosed in 15 of the 47 herds. The diagnosis of diarrhoea was based on clinical observations by a veterinarian at the time faeces were sampled. In a survey of 200 Swedish herds, which included the 47 herds used in this study, the incidence of farmer-diagnosed diarrhoea was $4.5 \%$ during the first month of the calves' life (Olsson et al. 1993). The lower frequency in the latter study may have been the result of not all cases of diarrhoea having been reported by the farmers. However, in both the study by Olsson et al. (1992) and the present one, the frequency of diarrhoea was low in comparison with results from studies in other countries (Roy 1990). One possible explanation could be the relatively small size of the farms involved, which are believed to have a lower infection pressure than large farms. In this investigation, at least 1 of the 3 pathogens studied could be detected in 11 out of 20 (55\%) faecal samples from diarrhoeic calves. The fact that no infectious agent was found in the remaining 9 samples may have been due to any of several factors, e.g.: shedding of the agent did not coincide with the sampling occasion, other agents than the 3 examined had caused the diarrhoea, the diarrhoea observed was not caused by an infectious agent, or inadequate diagnostic methods had been employed. However, the detection rate of pathogens in diarrhoeic samples in this study (55\%) 
is close to results from a Finnish survey, including 8 farms with recurrent outbreaks of enteric disturbances, in which at least 1 of the pathogens rotavirus, enteropathogenic $E$. coli and Cryptosporidium sp. was associated with diarrhoea in $75 \%$ of the cases (Pohjola et al. 1986).

The results indicate that rotavirus is a common finding in connection with diarrhoea in calves also in Sweden. Rotavirus antigen was detected in $9(45 \%)$ of 20 faecal samples from calves with diarrhoea, whereas the virus antigen was only found in $6(2.3 \%)$ of 259 non-diarrhoeic samples. It is not known if any of these 6 calves had recently had diarrhoea or had developed diarrhoea later. Absence of significant association between the microorganisms E. coli $\left(\mathrm{K}^{9} 9^{+}\right)$and Cryptosporidium sp. and diarrhoea (Table 1) cannot be fully interpreted due to the small number of cases of diarrhoea observed in this investigation and the ages ( $<14$ days) of calves studied. Cryptosporidiosis is most common in calves 10-20 days old, usually peaking at about 14 days (Krogh \& Henriksen 1985). Further-

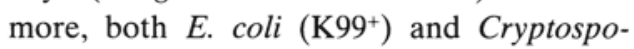
ridium $\mathrm{sp}$. have been repeatedly documented in Denmark, Finland and Sweden in connection with outbreaks of severe diarrhoea in calves (e.g. Viring et al. 1985, Sihvonen \& Miettinen 1985). In Denmark, Cryptosporidium has been detected in $24.8 \%$ of 8 -14-dayold calves with diarrhoea (Krogh \& Henriksen 1985).

The concentrations of total protein and $\gamma$ globulin in serum were somewhat lower in calves with diarrhoea than in non-diarrhoeic calves, but the differences were not significant (Table 2). Most of the studies carried out on this subject have observed a close relation between low concentration of $\gamma$-globulin and high prevalences of enteritis, septicaemia and mortality among calves (for a review, Han- cock, 1983). However, in the present study, the incidence of diarrhoea was low, the mean serum concentration of $\gamma$-globulin was low $(5.9 \mathrm{~g} / \mathrm{l})$ and 204 of $284(72 \%)$ calves had $\gamma$ globulin values lower than $8 \mathrm{~g} / \mathrm{l}$ at 7 days of age and may therefore be considered to have had an inadequate gammaglobulin level. By contrast, Möllerberg et al. (1989) reported a mean $\gamma$-globulin value of $11.6 \mathrm{~g} / 1$ in 8 days old calves which had received 2 litres of colostrum within $5 \mathrm{~h}$ of birth and a total amount of colostrum during the first day of life corresponding to $15 \%$ of their body weight. Dobbelaar et al. (1987) also found higher mean $\gamma$-globulin concentrations $(14.4 \mathrm{~g} / \mathrm{l})$ in calves younger than 6 days, than observed in the present study. However, the latter authors found substantial herd-related differences in $\gamma$-globulin concentrations. In most herds with low $\gamma$-globulin levels in calves, colostrum was served in buckets. This method is most commonly used in Sweden and may help explain the low concentrations of $\gamma$-globulin among calves observed in this study.

Calves born between May and September had a $2.0 \mathrm{~g} / \mathrm{l}$ higher $(\mathrm{p}<0.001)$ concentration of $\gamma$ globulin than calves born between October and April. This seasonal variation in concentrations concurs with results of other authors (Hurvell \& Fey 1970, Gay et al. 1983, Norheim \& Simensen 1985), but the reason for the variation remains unidentified. We also found a significant $(p=0.05)$ correlation between the quantity of first colostrum fed and total protein in calves' serum, which agrees with the results published by Dobbelaar et al. (1987) and by Norheim \& Simensen (1985) - but not with those of Pivont et al. (1984).

In conclusion, the present investigation indicates that the prevalence of neonatal diarrhoea is fairly low in Swedish dairy herds in spite of inadequate intake of colostrum as indicated by low levels of $\gamma$-globulin in the 
calves' sera. The study has also confirmed the importance of rotavirus as a cause of bovine neonatal diarrhoea also under Swedish conditions.

\section{Acknowledgements}

The veterinarians involved in sampling and recording are gratefully acknowledged. The authors also express their thanks to Dr Lennart Thunberg, Department of Clinical Chemistry, Swedish University of Agricultural Sciences, Uppsala for the description of the immunoglobulin methods. This work was made possible by funding from the Farmers' Research Council for Information and Development.

\section{References}

Baker JC: Bovine viral diarrhea virus: A review. J. Amer. vet. med. Assoc. 1987, 190, 1449-1458.

Blom JY: The relationship between serum immunoglobulin values and incidence of respiratory disease and enteritis in calves. Nord. Vet. Med. 1982, 34, 276-284.

Bridger JC, Woode GN, Meyling A: Isolation of coronavirus from neonatal calf diarrhoea in Great Britain and Denmark. Vet. Microbiol., 1978, 3, 101-113.

Cowan ST, Steel KJ: Manual for Identification of Medical Bacteria. Cambridge University Press, 2nd edn, 1974, p 238.

De Rycke J, Bernard S, Laporte J, Naciri M, Popoff $M R$, Rodolakis A: Prevalence of various enteropathogens in the feces of diarrheic and healthy calves. Ann. Rech. Vét. 1986, 17, 159-168.

Dobbelaar P, Noordhizen JPTM, van Keulen KAS: An epidemiological study of gammaglobulin levels in newborn calves. Prev. Vet. Med. 1987, 5, 5162.

Gay CC, McGuire TC, Parish SM: Seasonal variation in passive transfer of immunoglobulin $\mathrm{G} 1$ to newborn calves. J. Amer. vet. med. Assoc., 1983, 183, 566-568.

Hancock D: Epidemiological diagnosis of neonatal diarrhoea in dairy calves. The Bovine Proceedings 1983, No. 15, 16-22.

Hurvell B, Fey H: Comparative studies on the gammaglobulin level in sera of market calves in relation to their health. Acta vet scand. 1970, 11, 341360 .
Krogh HV, Henriksen SA: Bovine cryptosporidiosis in Denmark. 1. Prevalence, age distribution and seasonal variation. Nord. Vet. Med. 1985, 37, 3441.

Krogh $H V$ : Uspecifik enteritis hos spaedekalve [Non-specific enteritis in neonatal calves]. Medl. blad Dansk Dyrl. Foren. 1971, 54, 41-46.

Kruse V: Yield of colostrum and immunoglobulin in cattle at first milking after parturition. Anim. Prod. 1970a, 12, 619-626.

Kruse V: Absorption of immunoglobulin from colostrum in newborn calves. Anim. Prod. 1970b, 12, 627-638.

Larsson $B$ : The relationship between total protein in serum glutaraldehyde coagulation test and disease in feed of calves. Nord. Vet. -Med. 1985, 37, 90-96.

Linthermans $P$, Pohl P: Salmonella infection in calves and piglets. Ann. Rech. Vét. 1983, 14, 412419.

Logan EF, Penhale WJ, Jones RA: Changes in the serum immunoglobulin levels of colostrum-fed calves during the first 12 weeks postpartum. Res. Vet. Sci. 1972, 14, 394-397.

Moreno-López JWS, Jacobsson SO: Rotavirus vid kalvdiarré i Sverige (Rotavirus at calf diarrhoea in Sweden). SvenskVet. Tidn. 1978, 30, 565-567.

Möllerberg L, Jacobsson SO, Larsson B, Alenius S: Kliniskt-kemiska och hämatologiska normalvärden för SRB-kalvar [Clinical-chemical and haematological reference values in Swedish Red and White calves]. Svensk Vet. Tidn. 1989, 41, 713--720.

Nakane PK, Kawoi KS: Peroxidase-labelled antibody. A new method of conjugation. J. Histochem. Cytochem. 1974, 22, 1084-1091.

Nichols G, Thom BT: Screening for Cryptosporidium in stools. Lancet 1984, i(8379), 735.

Norheim K, Simensen E: An epidemiological study of factors affecting serum IgG levels in dairy calves. Nord. Vet. Med. 1985, 37, 121-135.

Olsson SO, Viring S, Emanuelsson U, Jacobsson SO: Calf diseases and mortality in Swedish dairy herds. Acta vet. scand. 1993, 34, 000-000.

Pivont P, Gregoire R, Antoine H: Investigation on farmer's colostrum feeding methods: habits affecting colostral status in neonatal calves. Ann. Rech. Vét. 1984, 15, 509-513.

Plöger W, Buitkamp J, Neumann W, Bechmann G, Reuss W: Untersuchungen über die Ursachen der Kälbersterblichkeit im nordwestdeutschen Küstengebiet [Studies of the ethiology of the calf 
mortality in the northwest coast area of Germany]. Tierärtzl. Umschau, 1980, 35, 659671.

Pohjola S, Oksanen H, Neuvonen E, Veijalainen P, Henriksson $K$ : Certain enteropathogens in calves of Finnish dairy herds with recurrent outbreaks of diarrhoea. Prev. Vet. Med., 1986, 3, 547-558.

Roy JHB: The Calf, 5th edn., Butterworths, London, 1990, 53-117.

Sihvonen L, Miettinen P: Rotavirus and enterotoxigenic Escherichia coli infections of calves on a closed Finnish dairy farm. Acta vet. scand. 1985, 26, 205-217.

Smyth CJ, Olsson E, Moncalvo C, Söderlind O, Orskov F, Orskov I: K99 antigen-positive enterotoxigenic Escherichia coli from piglets with diarrhoea in Sweden. J. clin. Microbiol. 1981, 13, 252-257.

Tizard I: Veterinary immunology: An introduction (3rd ed.). W.B. Saunders Company, Philadelphia, 1987, pp. 171-184.

Tzipori S: The aetiology and diagnosis of calf diarrhoea. Vet. Rec. 1981, 108, 510-514.

Viring S, Bornstein S, Jacobsson SO, Ström CH: Cryptosporidier påvisade vid besättningsutbrott av kalvdiarré [Cryptosporidia demonstrated at outbreak of diarrhoea in calves] Svensk Vet. Tidn. 1985, 37, 1, 24-26.

\begin{abstract}
Sammanfattning
Studier av enteritframkallande mikroorganismer och $\gamma$ globulinnivåer hos neonatala kalvar i Sverige.
\end{abstract}

Från 47 mjölkkobesättningar med 20-50 kor per besättning belägna i olika delar av Sverige togs under perioden september 1987 till oktober 1988 träck- och blodprover från $10-30 \%$ av kalvarna i åldern 36 timmar till 14 dagar. Proven togs oavsett om kalvarna hade diarré eller ej.

Av 279 träckprov som analyserades avseende Escherichia coli $\left(\mathrm{K}^{9} 9^{+}\right)$, Cryptosporidium sp. och rotavirus var $20(7,2 \%)$ från kalvar med diarré. Samband förelåg mellan förekomst av rotavirus och diarré $(\mathrm{p}<0,001)$, och mellan samtidig förekomst av rotavi-

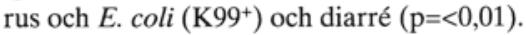

Blodprover från 327 kalvar undersöktes med avseende på totalprotein och $\gamma$-globulin i serum. I 43 prov $(13 \%)$ kunde $\gamma$-globulin ej skiljas från $\beta_{2}$-globulin med elektrofores. Den genomsnittliga nivån av totalprotein var $53,6 \mathrm{~g} / \mathrm{l}$ på kalvar som ej hade diarré. Gammaglobulinnivån korrigerad till 7 dygns ålder var 5,9 g/l. De 20 diarrékalvarna hade lägre såväl totalproteinvärden som $\gamma$-globulinvärden än kalvar utan diarré, men skillnaderna var ej statistiskt signifikanta.

En ökning av den första råmjölksgivan med 1 liter råmjölk visade sig höja totalproteinvärdet med 1,4 $\mathrm{g} / \mathrm{l}(\mathrm{p}=0,05)$. I medeltal var $\gamma$-globulin nivån $2,0 \mathrm{~g} / \mathrm{l}$ högre hos kalvar födda mellan maj och september jämfört med kalvar födda mellan oktober och april.

(Received March 5, 1993; accepted March 11, 1993).

Reprints may be requested from: S. Viring, Animal Health Service, Swedish Meat Marketing Association, National Veterinary Institute, Box 7073, S-750 07 Uppsala, Sweden. 